\title{
Increasing the load carrying capacity of highly loaded gears by nitriding
}

\author{
Johannes Koenig ${ }^{1, *}$, Stefanie Hoja ${ }^{2}$, Thomas Tobie ${ }^{1}$, Franz Hoffmann ${ }^{2,3}$ and Karsten Stahl ${ }^{1}$ \\ ${ }^{1}$ Gear Research Centre (FZG), Technical University of Munich, 85748 Garching b. München, Germany \\ ${ }^{2}$ Leibniz Institute for Materials Engineering - IWT, 28359 Bremen, Germany \\ ${ }^{3}$ Professor Hoffmann Werkstofftechnik, 28757 Bremen, Germany
}

\begin{abstract}
Nitriding is a common heat treatment process for highly loaded gears. A very hard compound layer with a thickness of a few microns is produced at the surface of the gear. In the underlying material areas, a diffusion layer with nitride precipitations is formed. This publication summarizes the state of knowledge of nitrided gears and gives an overview of the current state of research in the field of nitrided gears. It can be concluded that a high load carrying capacity of nitrided gears is dependent on an adequate NHD and a stable compound layer. However, due to the increased surface roughness after nitriding, the risk of micropitting increases, too. Therefore, it may be favourable to grind the gears after nitriding. Ground gears also can provide a high load carrying capacity, but it must be taken into account that the wear performance will decrease significantly, since it is mainly influenced by the compound layer. In addition, nitrided gears usually show a high sensitivity against local load peaks. Beyond creating a stable compound the layer, the realization of a sufficient nitriding hardness depth with larger gear sizes is a focus in the current field of research.
\end{abstract}

\section{Introduction}

Nitriding is - besides case hardening - a common heat treatment process for highly loaded gears. Nitriding creates a thin but very hard compound layer at the surface in combination with a diffusion layer underneath. The purpose of the nitriding treatment is to change the chemical composition of the microstructure by thermal and chemical reactions, whereby certain characteristics of the material are altered. As a result of nitride formation, the hardness in the case area increases as well as the thermal and fatigue strength. Furthermore, a higher resistance to corrosion, adhesive and abrasive wear can be achieved [1]. By applying nitriding after the grinding process, the advantages of the hard compound layer can be fully utilized. However, for some applications, it is more favourable to grind the gears after the nitriding process.

Compared to case hardened gears, where a lot of research has been undertaken in the last years [2-7], the knowledge on the load carrying capacity of nitrided gears is rather limited. However, within the German Drive Train Association (Forschungsvereinigung Antriebstechnik e.V.), the advantages, characteristics and possible shortcomings of nitrided gears were also investigated in several research projects [1, 8-11] by means of experimental tests on the tooth flank as well as on the tooth root load carrying capacity. This publication will focus especially on the different types of damages and effects from the nitriding process that mainly influenced these damages.

\section{Test Gears, Test Rigs and Test Conditions}

As part of the projects described herein, experimental tests were performed, addressing the load carrying capacity of both the tooth flank and the tooth root. For the investigations, several gear geometries specifically designed for the different purposes were used. The strength of the gears has been calculated according to ISO 6336 [12]. A detailed description of the calculation process is given in [13].

The details of the gear geometries of the test gears used are documented in Table 1 und

Table 2. The types 1,2 and 3 were used for investigations of the tooth flank load carrying capacity in gear running tests. For the investigations of the tooth root bending strength, the gears of types 2, 3 as well as gear geometry "Tooth Root" were used in tests on pulsating test rigs.

Table 1. Test gear geometry

\begin{tabular}{|l|c|c|c|}
\hline \multicolumn{1}{|c|}{ Parameter } & $\begin{array}{c}\text { Symbol } \\
{[\text { Unit] }}\end{array}$ & Type 1 & Type 2 \\
\hline Centre distance & $\mathrm{a}[\mathrm{mm}]$ & 91.5 & 91.5 \\
\hline Normal module & $\mathrm{m}_{\mathrm{n}}[\mathrm{mm}]$ & 4.5 & 5 \\
\hline Face width & $\mathrm{b}[\mathrm{mm}]$ & 14 & 14 \\
\hline Number of teeth & $\mathrm{z}_{1} / \mathrm{z}_{2}[-]$ & $16 / 24$ & $17 / 18$ \\
\hline $\begin{array}{l}\text { Normal pressure } \\
\text { angle }\end{array}$ & $\alpha_{\mathrm{n}}\left[{ }^{\circ}\right]$ & 20 & 20 \\
\hline Helix Angle & $\left.\beta{ }^{\circ}\right]$ & 0 & 0 \\
\hline Used in & {$[10,11]$} & {$[1,9]$} \\
\hline
\end{tabular}


Table 2. Test gear geometry

\begin{tabular}{|l|c|c|c|}
\hline \multicolumn{1}{|c|}{ Parameter } & $\begin{array}{c}\text { Symbol } \\
{[\text { Unit] }}\end{array}$ & Type 3 & $\begin{array}{c}\text { Tooth } \\
\text { Root }\end{array}$ \\
\hline Centre distance & $\mathrm{a}[\mathrm{mm}]$ & 52 & -- \\
\hline Normal module & $\mathrm{m}_{\mathrm{n}}[\mathrm{mm}]$ & 2 & 5 \\
\hline Face width & $\mathrm{b}[\mathrm{mm}]$ & 8 & 30 \\
\hline Number of teeth & $\mathrm{z}_{1} / \mathrm{z}_{2}[-]$ & $21 / 29$ & 18 \\
\hline Normal pressure angle & $\alpha_{\mathrm{n}}\left[^{\circ}\right]$ & 20 & 20 \\
\hline Helix Angle & $\beta\left[^{\circ}\right]$ & 0 & 0 \\
\hline Used in & {$[8]$} & {$[9]$} \\
\hline
\end{tabular}

\subsection{Tooth Root Bending Strength}

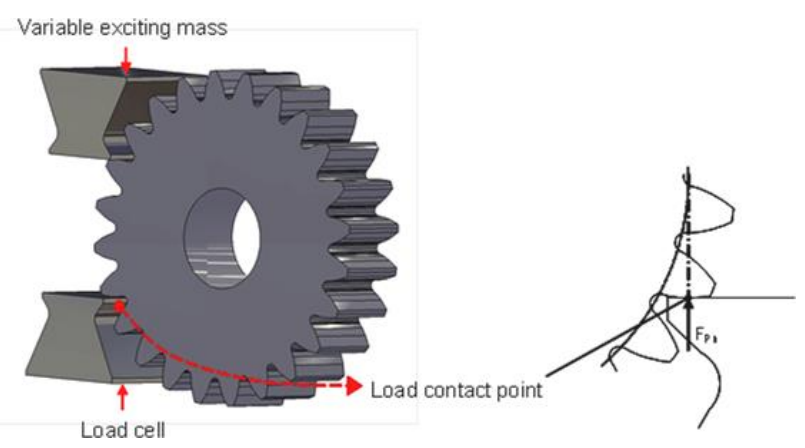

Fig. 1. Schematic representation of the load conditions in the pulsating test rig [2]

The bending fatigue tests, which were used to investigate the tooth root bending strength, were carried out by means of an electromagnetic pulsating test rig as well as on hydraulic pulsating test rigs. As shown in Fig. 1, the test gears were symmetrically clamped and usually tested over four teeth between two jaws. The exact position of the test gear in relation to the clamp jaws (i.e. the exact angle and point of load incidence) was adjusted by means of a special jig. Flank angle deviations were compensated by means of a precision adjustment, so that a uniform load distribution over the whole face width can be assumed. [2]

\subsection{Tooth Flank Load Carrying Capacity}

The experimental investigations of the load carrying capacity of the tooth flank were carried out on FZG back-to-back gear test rigs [14], as shown in Fig. 2.

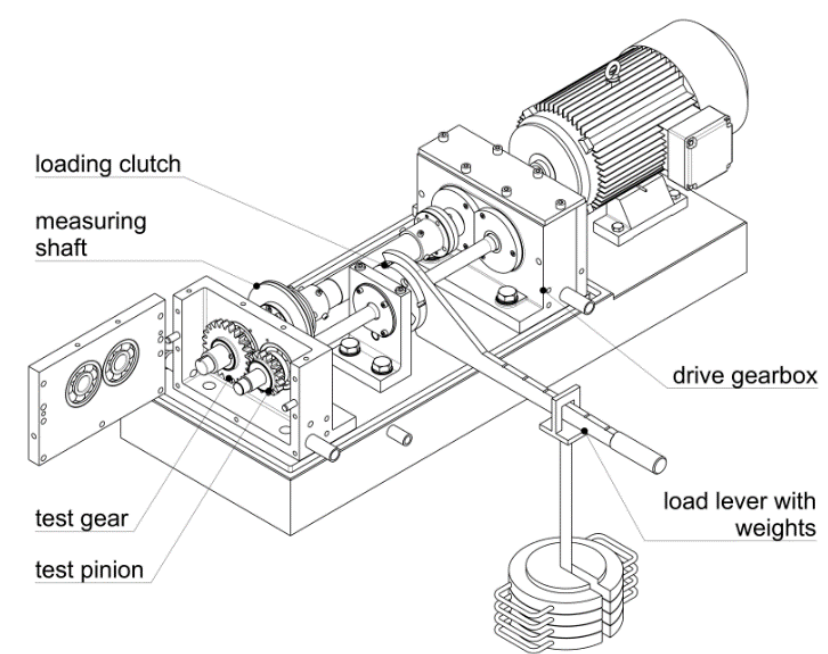

Fig. 2. FZG back-to-back gear test rig (schematically) [14]

A three-phase asynchronous engine drives the test rig. Test pinion and test gear are mounted on two parallel shafts, which are connected to a drive gear stage with the same gear ratio. The shaft of the test pinion consists of two separate parts that are connected by a load clutch. A defined static torque is applied by twisting the load clutch using defined weights on the load lever or by twisting the load clutch with a bracing device. The torque can be controlled indirectly at the torquemeasuring clutch as a twist of the torsion shaft. The test conditions were chosen similar to the default test parameters acc. to ISO 6336 [12].

\section{Description of the Nitriding Process}

Nitriding is a common heat treatment process for steels that allows a significant increase of both the load carrying capacity of the tooth flank and the tooth root. During the nitriding process, diffusible nitrogen is generated by surface reactions with the material. Since there is a concentration gradient, this nitrogen diffuses into the material. Thus, a concentration profile with high nitrogen contents in the surface near region of the material and lower nitrogen contents in the deeper regions builds up during the treatment. As soon as the solubility of nitrogen in the base material is exceeded, nitride precipitations begin to form within the diffusion zone [15]. First $\gamma$ '-nitrides with a nitrogen content of about 6 weight- $\%$ grow at the surface. At higher nitrogen contents these face-centered cubic $\gamma^{\prime}$-nitrides transform into the hexagonal $\varepsilon$-nitride [16]. With increasing nitriding time these nitride precipitations coalesce into a closed surface layer, the so-called compound layer, also known as white layer. The compound layer is usually a few microns thick and has a small porous zone near the surface. These pores form due to the recombination of excess nitrogen to molecular nitrogen [17]. The hardness of the compound layer is much higher than that of the base material [18]. Since the compound layer consists of nitride phases, the wear and corrosion resistance is increased compared to the base material [18]. Beneath the compound layer lays the diffusion layer. The hardness profile of the diffusion layer goes along with 
the nitrogen profile, since the hardness is increased by the dissolved nitrogen and the nitride precipitations [18]. A quantity of the diffusion depth is the nitriding hardness depth (NHD). For gears, NHD is defined as the distance from the surface into the material to the point at which the hardness value drops below 400 $\mathrm{HV}$. If the core hardness exceeds $380 \mathrm{HV}$, a value of "core hardness $+50 \mathrm{HV}$ " may be applied as hardness limit. [12]

The increase of the load carrying capacity of nitrided gears regarding pitting and bending is depending on the nitriding hardening depth (NHD), with adequate nitriding hardening depths leading to an optimum load carrying capacity. In general, larger gear sizes require a higher nitriding hardening depth (NHD). The NHD is usually limited to NHD $\leq 0.6 \mathrm{~mm}$, since higher NHD values will significantly increase the processing times. Therefore, for larger gears, case hardening is more frequently used. [9]

However, nitriding has some advantages over case hardening. One of the main advantages of nitriding compared to case hardening - is the lower distortion. Therefore, a common manufacturing chain for nitrided gears is the application of the nitriding process to ground gears with no further finishing of the gears being necessary. However, in order to ensure a sufficient gear quality and tooth flank roughness after the nitriding, the tooth flanks must be prepared well prior to the heat treatment. One effect that must be taken into account is the thickness of the compound layer, which grows faster at the edges of the flank than in the middle. Therefore, adequate profile and lengthwise modifications, e.g. tip and end relief must be applied to avoid critical side effects due to bulges at the edges. The gear geometry and the surface roughness of the tooth flank are also slightly affected, i.e. by the formation of pores. Consequently, a high quality of the gears and a low surface roughness before nitriding should be ensured. In order to avoid the negative effects of the nitriding process, another possible way of manufacturing is grinding of the gears after nitriding. This will remove the compound layer from the surface and consequently, the corrosion resistance, which was improved by the compound layer, decreases. However, due to the grinding after nitriding, a comparatively high gear quality and low surface roughness can be achieved. [9]

\section{Load Carrying Capacity of Nitrided Gears}

In order to evaluate the load carrying capacity of gas nitrided gears, experimental investigations were carried out as part of the research projects FVA 386 I [1], FVA 386 II [8], FVA 615 II [9] and FVA 482 IV [11]. For the investigations, several heat treatable and nitriding steels such as 31CrMoV9 (1.8519), 30CrNiMo8 (1.6580), 15CrMoV5-9 (1.8521) and 32CDV13 were used. Both the tooth flank load carrying capacity and the tooth root bending strength were investigated.

\subsection{Tooth Root Bending Strength}

As part of FVA 386 I+II [4, 7] and FVA 615 II [9], the tooth root bending strength of nitrided gears has been investigated intensively. The investigations were limited to gears that did not receive any further machining after nitriding, so the compound layer at the surface was intact.

Fig. 3 shows the experimental determined tooth root bending strength of the nitrided gears, which were investigated in the research projects FVA $386 \mathrm{I}+\mathrm{II}[1,8]$. The determined tooth root bending strength for the nitrided gears was in the area of the quality MQ to ME according to ISO 6336-5 [12] and thereby much better than that of only quenched and tempered gears. [8]

The effects of an increased nitriding hardening depth (NHD) were investigated in FVA 615 II [9]. Here, the calculated tooth root bending strength of the nitrided gears was even higher as specified in ISO 6336-5 [12] and comparable to the tooth root bending strength of case hardened and shot peened gears of the same size.

For the review of the determined tooth root bending strength, it must be taken into account, that in all three research projects the variation of the results was relatively high and a nameable number of gears failed by fracture of the tooth root after few load cycles. These gears were further investigated in FVA 386 II [8]. The cracks started at the $30^{\circ}$ tangent of the tooth root rounding so it was concluded, that the maximum tension was decisive for the fracture. The tooth root fractures in FVA 615 II [9] occurred at relatively low load cycles, too. This indicates also a high sensitivity of the nitrided gears for loads exceeding the endurance limit.

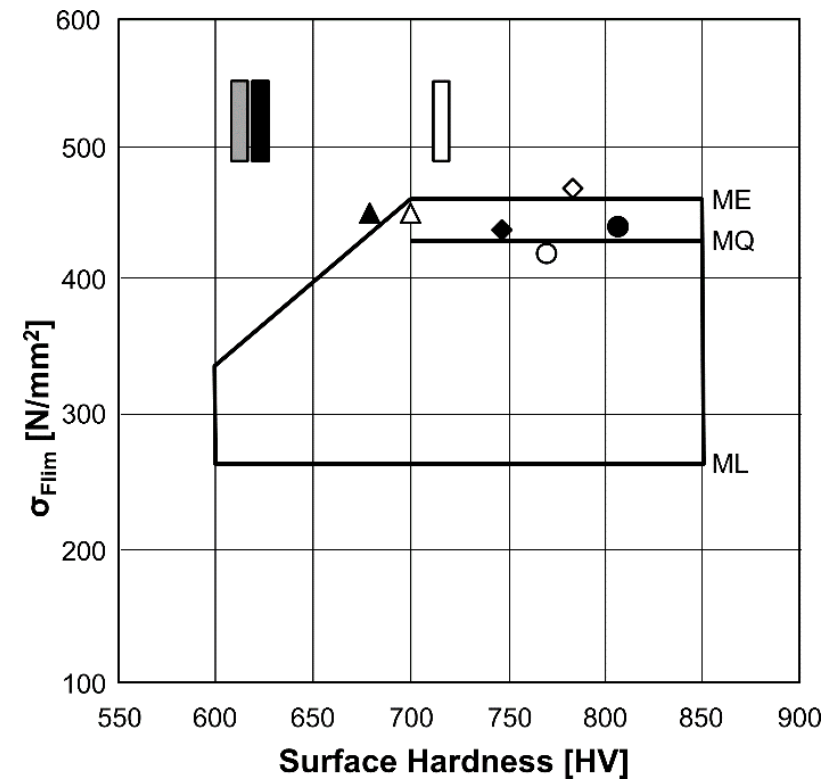
A $31 \mathrm{CrMoV} 9\left(510^{\circ} \mathrm{C}, \mathrm{K}_{\mathrm{N}}=0.4, \mathrm{NHD} \approx 0,6 \mathrm{~mm}\right)[1]$
$\triangle 31 \mathrm{CrMoV} 9\left(510^{\circ} \mathrm{C}, \mathrm{K}_{\mathrm{N}}=0.8, \mathrm{NHD} \approx 0,6 \mathrm{~mm}\right)[1]$
O $31 \mathrm{CrMoV} 9\left(520^{\circ} \mathrm{C}, \mathrm{K}_{\mathrm{N}}=1.0, \mathrm{NHD} \approx 0,6 \mathrm{~mm}\right)[8]$
$\checkmark 15$ CrMoV5-9 $\left(510^{\circ} \mathrm{C}, \mathrm{K}_{\mathrm{N}}=0.4, \mathrm{NHD} \approx 0,5 \mathrm{~mm}\right)$ [1]
$\diamond 15$ CrMoV5-9 $\left(510^{\circ} \mathrm{C}, \mathrm{K}_{\mathrm{N}}=0.8, \mathrm{NHD} \approx 0,5 \mathrm{~mm}\right)[1]$
$15 \mathrm{CrMoV} 5-9\left(520^{\circ} \mathrm{C}, \mathrm{K}_{\mathrm{N}}=1.0, \mathrm{NHD} \approx 0,4 \mathrm{~mm}\right)[8]$
$32 \mathrm{CDV} 13\left(570{ }^{\circ} \mathrm{C}, \mathrm{K}_{\mathrm{N}}=0.5, \mathrm{NHD} \approx 1,0 \mathrm{~mm}\right)[9]$
a $31 \mathrm{CrMoV} 9\left(530^{\circ} \mathrm{C}, \mathrm{K}_{\mathrm{N}}=0.5, \mathrm{NHD} \approx 1,0 \mathrm{~mm}\right)$ [9] 
$30 \mathrm{CrNiMo} 8\left(530^{\circ} \mathrm{C}, \mathrm{K}_{\mathrm{N}}=0.5, \mathrm{NHD} \approx 1,0 \mathrm{~mm}\right)[9]$

Fig. 3. Test results for the Tooth Root Bending Strength of nitrided gears acc. to FVA 386 I+II [1, 8] and FVA 615 II [9] and comparison with the specified strength numbers for nitrided gears acc. to ISO 6336 [12]

\subsection{Flank Load Carrying Capacity}

The flank load carrying capacity has been investigated on as-nitrided gears with intact compound layer as well as on gears, where the compound layer was removed by grinding. For both the gears with and without the compound layer, respectively, a pitting endurance within the expectations of ISO 6336-5 [12] has been determined. The observed damage characteristics, however, were different between the variants.

The passed specimen of the gears with an intact compound layer were free of micropitting. The failed gears however, showed severe micropitting on the tooth flanks before the gears eventually failed due to pitting. In contrast to that, some of the gears without compound layer, which failed due to pitting, did not show any micropitting before. If no micropitting has been observed, the overall pitting endurance of the gears with compound layer was higher, compared to the variants that were ground after nitriding. If micropitting occurred, both variants showed a comparable pitting performance. [8]

As part of the project FVA 615 II [9], gears with increased nitriding depth of up to $1 \mathrm{~mm}$ (deep nitriding) have been investigated. The gears investigated in FVA 615 II were ground before the nitriding process. The increased NHD values have been achieved by increasing the nitriding temperature and the nitriding time in a twostage nitriding process. Details of the heat treatment can be found in [19]. Due to the increased nitriding temperature and time, the negative effects such as edge bulges, increased gear roughness and reduced gear quality were slightly increased compared to a state-ofthe-art nitriding process. Also, the core hardness is slightly reduced due to tempering effects [20].

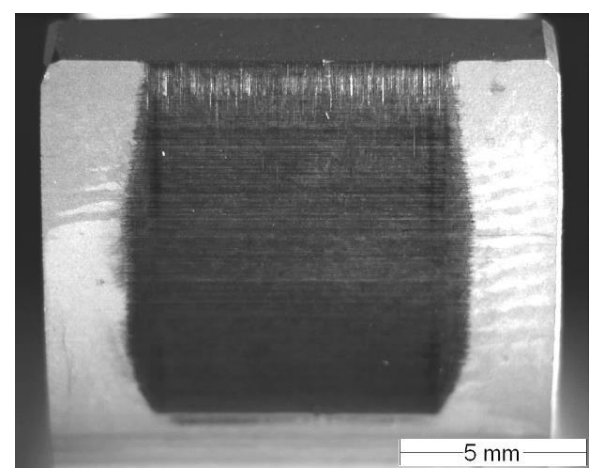

Fig. 4. Tooth flank picture of the deep nitrided gear, material 32CDV13, after 30 million cycles $\left(\sigma_{\mathrm{H} 0}=2050 \mathrm{~N} / \mathrm{mm}^{2}\right.$, passed specimen) [9]
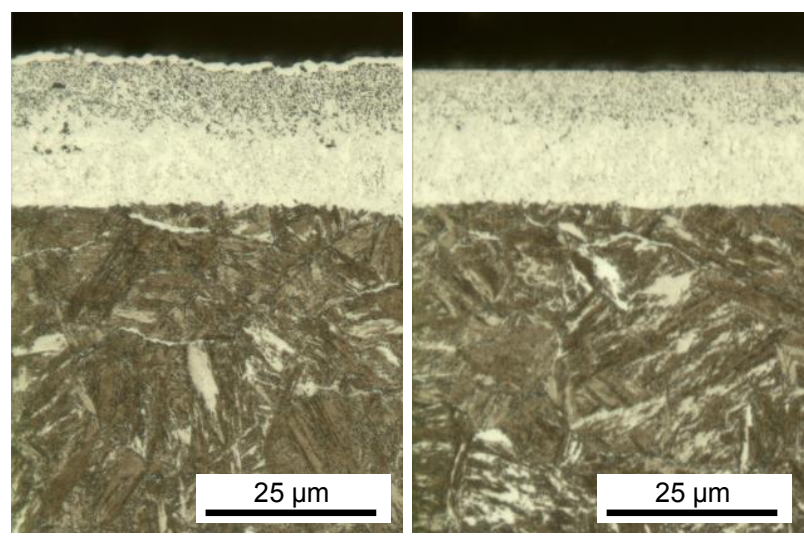

a) as-nitrided in new condition b) after 30 million load cycles

Fig. 5. Compound layer of a deep nitrided gear, material $32 \mathrm{CDV} 13$ ( $\sigma_{\mathrm{H} 0}=2050 \mathrm{~N} / \mathrm{mm}^{2}$, passed specimen) [9]

The results of the experiments on the back-to-back gear test rig again showed a dependence on whether the compound layer stayed intact on the tooth flank during the test run or whether it started to delaminate. In Fig. 4, the tooth flank picture of a highly loaded flank is shown after 30 million load cycles. On the surface, no defects can be observed visually. A metallographic cross section of the compound layer of the deep nitrided material 32 CDV13 is shown in Fig. 5. The comparison of the asnitrided state and the state after 30 million cycles shows, that for this material and heat treatment, the compound layer stayed intact during the test run. As a result, the gear passed the running test at a high load and the tooth flank does not show any wear, micropitting or pitting.

In Fig. 6, a tooth flank of a gear made from another nitriding steel is shown. The deep nitriding treatment was carried out with different heat treatment parameters due to the lower temperature resistance of the material $30 \mathrm{CrNiMo} 8$ (1.6580) at long nitriding times [20]. On the tooth flank, a combination of micropitting and pitting is visible after only 6 million load cycles on a load level which was much lower, compared to the variant shown in Fig. 4. Fig. 7 shows the cross section of the compound layer. Due to the lower nitriding temperature, the compound layer in the as-nitrided state is much thinner than that of the material 32CDV13 shown in Fig. 5. After the running test, many cracks in the thin compound layer could be observed. One of them is exemplary shown in Fig. 7. As a conclusion, it can be stated, that as long as the compound layer remains intact, a high load carrying capacity of the tooth flank can be achieved. However, if the compound layer gets damaged or starts to delaminate, this significantly reduces the flank load carrying capacity. 


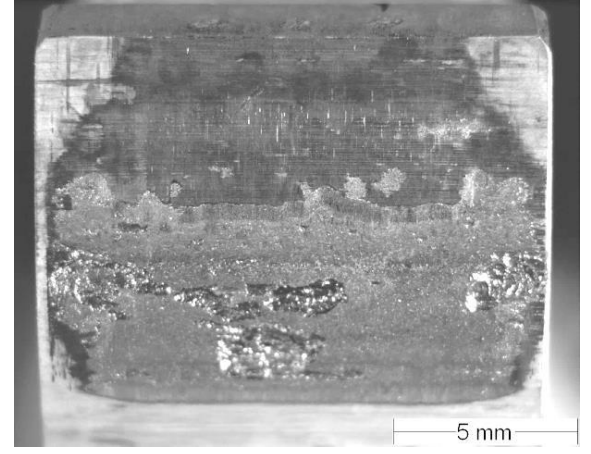

Fig. 6. Tooth flank picture of the deep nitrided gear, material 30CrNiMo8, after 6 million cycles

$\left(\sigma_{\mathrm{H} 0}=1450 \mathrm{~N} / \mathrm{mm}^{2}\right.$, pitting failure) [9]

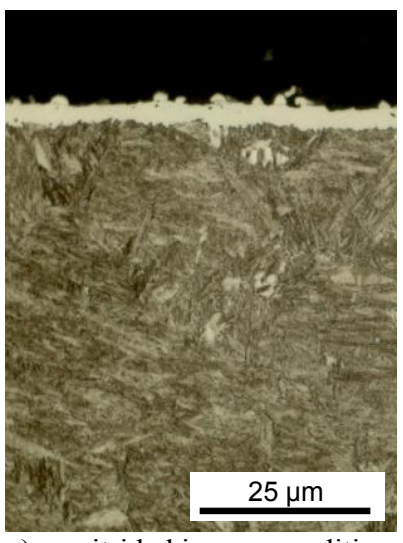

a) as-nitrided in new condition

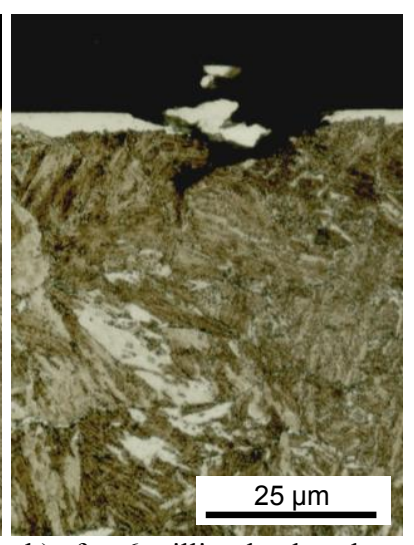

b) after 6 million load cycles
Fig. 7. Compound layer of a deep nitrided gear, material $30 \mathrm{CrNiMo} 8\left(\sigma_{\mathrm{H} 0}=1450 \mathrm{~N} / \mathrm{mm}^{2}\right.$, pitting failure) [9]

\subsection{Micropitting and Wear Performance}

In the research project FVA 482 IV [11], the micropitting and wear performance of nitrided gears has been investigated. The results were compared to FVA 482 I [10], where similar investigations have been done by means of case hardened gears. The gears, which were compared to case hardened gears, were nitrided in an industrial gaseous nitriding process $\left(510^{\circ} \mathrm{C} 30 \mathrm{~h}\right)$. After nitriding, there was no further machining applied.

The wear performance has been tested according to DGMK 377 [21]. The gears were lubricated with the FVA reference oil $3+4 \%$ Anglamol99 (FVA 3A) [22]. In comparison to the case hardened test variant, the nitrided gears in general showed a much better wear performance.

In further tests, the influence of the nitrided layer, i.e. compound layer thickness (CLT), composition of the compound layer, thickness of the porous layer $\left(\mathrm{CLT}_{\mathrm{P}}\right)$ as well as the influence of the nitriding hardness depth (NHD), on the micropitting and wear performance was investigated. By a variation of the nitriding parameters, different nitrided layers could be created on the material $31 \mathrm{CrMoV} 9$. The variations of the nitrided layer, which were tested in this research, are shown in Table 3.

Table 3. Variations of NHD and/or nitrided layer for the micropitting and wear tests

\begin{tabular}{|l|l|l|l|l|}
\hline \multicolumn{1}{|c|}{ Variant } & $\begin{array}{l}\text { NHD } \\
{[\mathbf{m m}]}\end{array}$ & $\begin{array}{l}\text { CLT } \\
{[\boldsymbol{\mu m}]}\end{array}$ & $\begin{array}{l}\text { CLT } \\
{[\boldsymbol{\mu m}]}\end{array}$ & \multicolumn{1}{|c|}{$\begin{array}{c}\text { nitride } \\
\text { phases }\end{array}$} \\
\hline $\begin{array}{l}\text { R (industrial } \\
\text { reference) }\end{array}$ & 0.38 & 11.4 & 3.7 & mainly $\varepsilon$ \\
\hline $\begin{array}{l}\text { PN (plasma } \\
\text { nitriding) }\end{array}$ & 0.48 & 7.9 & 2.2 & $\gamma^{6}$ \\
\hline NHD1 & 0.12 & 0.7 & 0 & $\gamma^{6}$ \\
\hline NHD2 & 0.22 & 2.6 & 0 & $\gamma^{6}$ \\
\hline CL1 & 0.43 & 4.1 & 0.5 & $\gamma^{6}$ \\
\hline CL2 & 0.53 & 12.6 & 4.5 & mainly $\gamma^{6}$ \\
\hline $\begin{array}{l}\text { NC (nitro- } \\
\text { carburising) }\end{array}$ & 0.43 & 17.6 & 4.3 & $\begin{array}{l}\text { mixture of } \\
\gamma^{6} / \varepsilon\end{array}$ \\
\hline
\end{tabular}

The investigations showed that the composition of the compound layer is the main influencing factor on the wear performance. The nitriding depth shows less influence, if a certain minimum thickness of the nitrided layer is ensured. Almost no influence has been determined for the type of material and the type of nitriding process, as long as the properties of the compound layer are similar. Fig. 8 and Fig. 9 show exemplary results of the wear tests on a case hardened and a nitrided tooth flank, respectively.

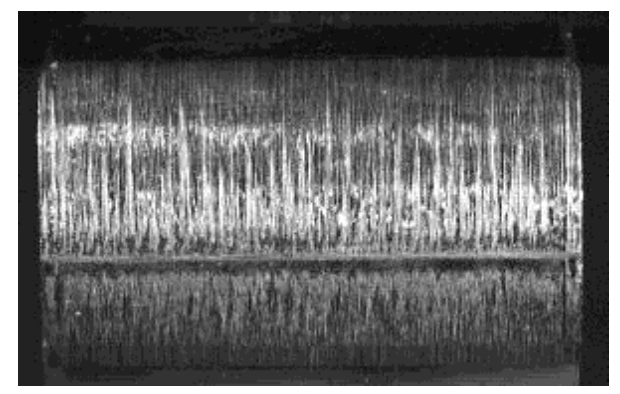

Fig. 8. Case hardened Toot Flank after Wear Test DGMK 377 [10]

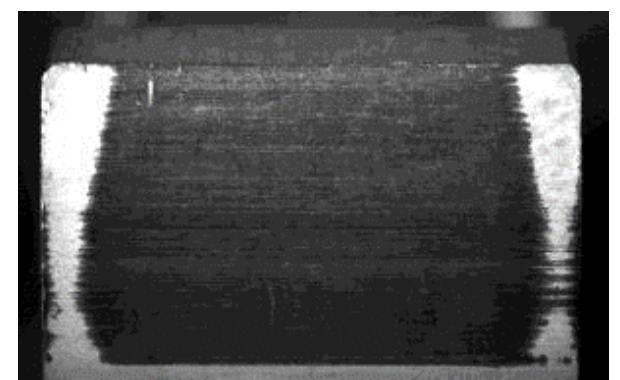

Fig. 9. Nitrided Tooth Flank after Wear Test DGMK 377 [11]

The micropitting performance has been investigated according to FVA 54 [23]. Again, reference oil FVA 3A has been used. Similar to the wear tests, the nitrided gears also performed significantly better in the micropitting test, compared to the case hardened gears. During the tests, the porous zone has been identified as one of the main influencing factors on the micropitting performance. As long as a sufficient thickness of the porous zone at the tooth flank can be ensured, no micropitting has been observed. However, it must be noted that the porous zone has decreased during the micropitting test. Consequently, this will lead to micropitting if no porous zone is left on the tooth flank. 
Fig. 10 and Fig. 11 show exemplary results of the micropitting tests on a case hardened and a nitrided tooth flank, respectively.

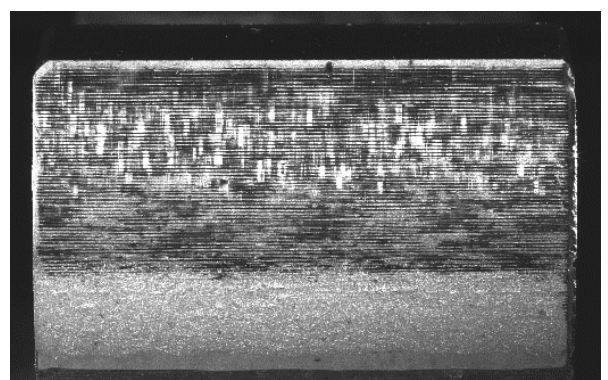

Fig. 10. Case hardened Tooth Flank after Micropitting Test FVA 54 [10]

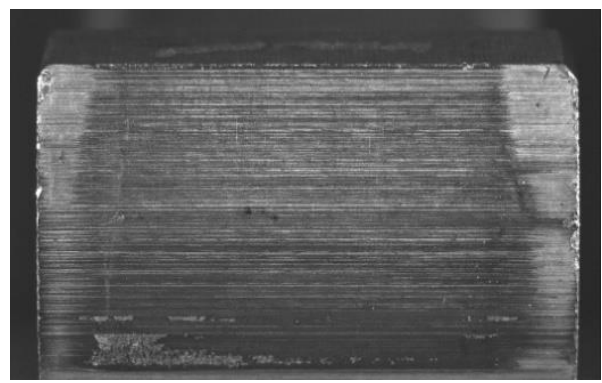

Fig. 11. Nitrided Tooth Flank after Micropitting Test FVA 54 [11]

Based on the results it can be concluded that in general the same principles as for case hardened gears on the formation of micropitting and/or wear apply [24]. However, for nitrided gears, the additional influence of the compound layer must be taken into account.

\section{Summary and Conclusions}

Nitriding is a common heat treatment for highly loaded gears. By nitriding, a thin but very hard surface layer - the compound layer - can be created, along with a diffusion layer underneath. As a result, the thermal and fatigue strength is significantly increased.

As part of several research projects within the German Drive Train Association (Forschungsvereinigung Antriebstechnik e.V.), the load carrying capacity of nitrided gears has been investigated intensively. For many applications, nitrided gears are not machined after nitriding, so the gears must be prepared appropriately in order to achieve a high load carrying capacity. This can be ensured e.g. by applying an adequate tip and end relief to avoid negative effects caused by edge bulges. The investigations showed that the compound layer significantly influences the resulting load carrying capacity. As long as the compound layer is intact, a high load carrying capacity can be ensured. However, it must be taken into account that the nitrided layer leads to an increased surface roughness as well as to a reduced quality of the gears. This may increase the risk of micropitting. Therefore, it may be favourable to grind the gears after nitriding. While this removes the hard compound layer at the surface, both the surface roughness and gear quality can be influenced positively. The results of the investigations show that grinding after nitriding also can lead to a high load carrying capacity. However, if the compound layer is removed after nitriding, the micropitting and wear performance, which are mainly influenced by the compound layer, will decrease significantly. So, the nitriding and grinding process should always be chosen depending on the expected exposure.

A high load carrying capacity can be expected for nitrided gears with an adequate NHD and a stable compound layer. In this case, a tooth root load carrying capacity comparable to case hardened gears and a tooth flank load carrying capacity (pitting, micropitting and wear) even higher as for case hardened gears can be expected. However, it must be taken into account that especially the stability of the compound layer is a major influence factor on the load carrying capacity. If the compound layer is damaged or worn off, the load carrying capacity will be significantly reduced. In order to avoid micropitting and wear, a stable compound layer, an adequate gear quality and a low surface roughness is necessary.

It must be further taken into account that nitrided gears usually show a high sensitivity against local load peaks. In addition, with larger gear sizes, the realization of a sufficient NHD becomes more and more challenging. As a result, nitriding is usually chosen for gears of small to middle size and for applications with uniform loads. On larger gears, nitriding may be used to ensure a high micropitting and wear performance. In this case, the risk of a reduced pitting and/or tooth root load carrying capacity must be taken into account.

Further research is currently undertaken within the German Drive Train Association, for example on the effects of very high nitriding depths or on the composition of the compound layer on the load carrying capacity.

The authors like to thank Matthias Steinbacher and HansWerner Zoch for their contributions to the research projects that form the basis of this paper.

This work has been partly funded by the "Forschungsvereinigung Antriebstechnik e.V. (FVA)", the "Stiftung Stahlanwendungsforschung im Stifterverband für die Deutsche Wissenschaft e.V.“, the „Forschungsvereinigung der Arbeitsgemeinschaft der Eisen und Metall verarbeitenden Industrie e.V. (AVIF)“ and the „AiF Arbeitsgemeinschaft industrieller Forschungsvereinigungen - Otto von Guericke e.V. (AiF)“،.

\section{References}

1. D. Günther; P. Pouteau; S. Bruckmeier; F. Hoffmann; T. Tobie; P. Mayr; H.-W. Zoch; B.-R. Höhn: Nitrierte Zahnräder - Produktsicherheit nitrierter Zahnräder., Research project no. 386 (AVIF-Nr. A 162), Final report, FVA journal no. 777, Forschungsvereinigung Antriebstechnik e.V. (FVA), Frankfurt am Main, Germany (2005).

2. F. Dobler; D. Nadolski; T. Tobie; M. Steinbacher; K. Stahl; F. Hoffmann: Influence of hardening 
pattern, base material and residual stress condition on the tooth root bending strength of induction hardened gears. Proceedings of the International Conference on Power Transmissions 2016 (ICPT 2016) (2016).

3. P. Koller; S. Schwienbacher; P. Oster; T. Tobie; K. Stahl; B.-R. Höhn: Flank-Load-Carrying Capacity of Case Hardened Gears with Grinding Burn. ASME 2011 International Design Engineering Technical Conferences and Computers and Information in Engineering Conference, Washington, DC, USA (2012).

4. P. Koller; S. Schwienbacher; P. Oster; T. Tobie; K. Stahl; B.-R. Höhn: Grinding Burn on Gears Correlation between Flank-Load-Carrying Capacity and Material Characteristics. Dobre, G. The 4th International Conference on Power Transmissions, Sinaia, Romania (2013).

5. J. König; M. Felbermaier; T. Tobie; K. Stahl: Tribologische Einflussfaktoren auf die Entstehung von Graufleckigkeit an einsatzgehärteten Zahnrädern. Tribologie und Schmierungstechnik. 64, i. 2, 21-27 (2017).

6. J. König; P. Koller; T. Tobie; K. Stahl: Influence of additional surface finishing to the material properties and the flank load carrying capacity of case-hardened gears with grinding burn. Journal of Advanced Mechanical Design, Systems, and Manufacturing. 11, i. 6 (2017).

7. J. König; P. Koller; T. Tobie; K. Stahl: Correlation of Relevant Case Properties and the Flank Load Carrying Capacity of Case-Hardened Gears. American Society of Mechanical Engineers (ASME). ASME 2015 Power Transmission and Gearing Conference; 23rd Reliability, Stress Analysis, and Failure Prevention Conference, Boston, MA, USA (2015).

8. N. Bretl; S. Schurer; T. Tobie; K. Stahl; B.-R. Höhn: Nitrieren II - $\quad$ Ergänzungsvorhaben „Produktsicherheit nitrierter Zahnräder“., Research project no. 386 II, Final report, FVA journal no. 1025, Forschungsvereinigung Antriebstechnik e.V. (FVA), Frankfurt am Main, Germany (2012).

9. S. Hoja; S. Schurer; F. Hoffmann; T. Tobie; H.-W. Zoch; K. Stahl: Tiefnitrieren - Tiefnitrieren von Zahnrädern., Research project no. 615 II (AiF-Nr. 17321), Final report, FVA journal no. 1147, Forschungsvereinigung Antriebstechnik e.V. (FVA), Frankfurt am Main, Germany (2015).

10. J. Schudy; T. Tobie; B.-R. Höhn: Flankentragfähigkeit Innen-/Außenverzahnung Flankentragfähigkeit von innen- und außenverzahnten Stirnrädern bei geringen Umfangsgeschwindigkeiten., Research project no. 482 I (AVIF-Nr. A230), Final report, FVA journal no. 867, Forschungsvereinigung Antriebstechnik e.V. (FVA), Frankfurt am Main, Germany (2008).

11. B. Zornek; S. Hoja; T. Tobie; F. Hoffmann; K. Stahl; H.-W. Zoch: Nitrierte Innen-
/Außenverzahnung - Tribologische Tragfähigkeit nitrierter Innen- und außenverzahnungen bei geringen Umfangsgeschwindigkeiten., Research project no. 482 IV (AiF-Nr. 17730), Final report, FVA journal no. 1206, Forschungsvereinigung Antriebstechnik e.V. (FVA), Frankfurt am Main, Germany (2017).

12. ISO 6336:2006/2016: Calculation of load capacity of spur and helical gears. Beuth Verlag, Berlin, Germany (2006/2016).

13. M. Hein; M. Geitner; T. Tobie; K. Stahl; B. Pinnekamp: Reliability of gears - Determination of statistically validated material strength numbers. American Gear Manufacturers Assiciation (AGMA). AGMA Fall Technical Meeting 2018, Oak Brook, IL, USA (2018).

14. DIN ISO 14635-1:2006-05: Zahnräder - FZGPrüfverfahren - Teil 1: FZG-Prüfverfahren A/8,3/90 zur Bestimmung der relativen Fresstragfähigkeit von Schmierölen. Beuth Verlag, Berlin, Germany (2006).

15. H.-J. Spies; D. Bergner: Innere Nitrierung von Eisenwerkstoffen. HTM Journal of Heat Treatment and Materials. 47, i. 6, 346-356 (1992).

16. M. Hansen; K. Anderko: Constitutions of Binary Alloys. McGraw-Hill, New York, NY, USA (1958).

17. M. A. J. Somers; E. J. Mittemeijer: Verbindungsschichtbildung während des Gasnitrierens und des Gas- und Salzbadnitrocarburierens. HTM Journal of Heat Treatment and Materials. 47, i. 1, 5-13 (1992).

18. H.-J. Spies: Kontrolliertes Gasnitrieren von Eisenwerkstoffen. Stahl. 77-83, i. 2 (1992).

19. S. Hoja; F. Hoffmann; H.-W. Zoch; S. Schurer; T. Tobie; K. Stahl: Entwicklung von Prozessen zum Tiefnitrieren von Zahnrädern - Design of Deep Nitriding Treatments for Gears. HTM Journal of Heat Treatment and Materials. 70, i. 6, 276-285 (2015).

20. S. Hoja; F. Hoffmann; M. Steinbacher; H.-W. Zoch: Investigation of the Tempering Effect during Nitriding. HTM Journal of Heat Treatment and Materials. 73, i. 6, 335-343 (2018).

21. I. Bayerdörfer: Method to Assess the Wear Characteristics of Lubricants - FZG Test Method C/0,05/90:120/12., DGMK Information 337-01, Deutsche Wissenschaftliche Gesellschaft für Erdöl, Erdgas und Kohle e.V. (DGMK), Hamburg, Germany (1997).

22. E. M. Laukotka: Referenzölkatalog - Referenzöle Datensammlung., FVA journal no. 660, Forschungsvereinigung Antriebstechnik e.V. (FVA), Frankfurt am Main, Germany (2007).

23. S. Emmert; G. Schönnenbeck; H. Rettig; P. Oster; B.-R. Höhn; H. Winter: Graufleckigkeit Testverfahren zur Untersuchung des Schmierstoffeinflusses auf die Entstehung von Grauflecken bei Zahnrädern., FVA information 
sheet no. 54/7, Forschungsvereinigung Antriebstechnik e.V. (FVA), Frankfurt am Main, Germany (1993).

24. J. König; M. Felbermaier; T. Tobie; K. Stahl: Influence of low circumferential speeds on the lubrication conditions and the damage characteristics of case-hardened gears. 73rd Society of Tribologists and Lubrication Engineers Annual Meeting and Exhibition 2018 (2018). 